\title{
Biofilm polymers: relationship between carbohydrate biopolymers from estuarine mudflats and unialgal cultures of benthic diatoms
}

\author{
B. J. Bellinger ${ }^{1, *}$, A. S. Abdullahi ${ }^{1}$, M. R. Gretz ${ }^{1}$, G. J. C. Underwood ${ }^{2}$ \\ ${ }^{1}$ Department of Biological Sciences, Michigan Technological University, 1400 Townsend Drive, Houghton, \\ Michigan 49931, USA \\ ${ }^{2}$ Department of Biological Sciences, University of Essex, Wivenhoe Park, Colchester CO4 3SQ, UK
}

\begin{abstract}
Benthic microalgae (microphytobenthos) are the dominant group of primary producers in many marine intertidal and subtidal habitats. Estuarine mudflat diatoms are thought to be major contributors of extracellular polymeric substances (EPS), which are important for sediment stabilization and in benthic food chains. Biofilms from 6 sites in the Colne estuary, UK, were fractionated to isolate biopolymers (colloidal, colloidal EPS [cEPS], low molecular weight [LMW] carbohydrates, hot water [HW] and hot bicarbonate [HB] soluble) and the same techniques were applied to diatoms cultured from these sediments. At sites dominated by benthic diatoms, colloidal carbohydrate concentration and chlorophyll a were closely related. With increasing biomass, the proportion of cEPS within the colloidal fraction decreased from 60 to $20 \%$. Carbohydrate analysis revealed significant differences in monosaccharide and uronic acid composition of different carbohydrate fractions. Principal component analysis (PCA) of monosaccharide composition of HB polymers from both field and culture samples grouped closely along fucose and rhamnose vectors and formed 2 distinct clusters. HW and LMW fractions grouped along the glucose vector and cEPS polymers along the galactose and arabinose vectors. These data indicate that the simple relationship between colloidal carbohydrate concentration and microphytobenthic biomass in biofilms masks a high degree of potential complexity within the sediment carbohydrate pool and in the different proportions of polymeric and nonpolymeric material between different biofilms. Comparing monosaccharide composition of extracts generated using the same protocol, natural assemblages showed close relationships with unialgal cultures, confirming the important role of diatom-derived polymers in mudflat ecology.
\end{abstract}

KEY WORDS: Diatoms $\cdot$ Biofilms $\cdot$ Microphytobenthos $\cdot$ EPS $\cdot$ Monosaccharide distribution $\cdot$ Uronic acids $\cdot$ Biopolymers $\cdot$ Fractionation

Resale or republication not permitted without written consent of the publisher

\section{INTRODUCTION}

Estuarine soft sediments support a diverse consortium of eukaryotic and prokaryotic organisms (Underwood \& Paterson 2003). In muddy intertidal systems, these organisms can form transient, self-assembling biofilms at the sediment surface (Paterson et al. 2003). The microphytobenthic biofilms present are capable of annual production rates of up to $300 \mathrm{~g} \mathrm{C} \mathrm{m}^{-2}$ (Underwood \& Kromkamp 1999), and can have a major impact on carbon flow into benthic and planktonic communi- ties (Decho 1990, Underwood \& Paterson 2003, Stal 2003). Pennate diatoms (Bacillariophyceae) dominate the estuarine microphytobenthic flora (Round et al. 1990, Smith \& Underwood 1998). A significant adaptation of these organisms to their environment is the secretion of a range of extracellular materials, commonly referred to as extracellular polymeric substances (EPS). Many different functions have been ascribed to these polymers, including motility, desiccation resistance, mediation of extracellular exchange, and as a photosynthetic overflow (Hoagland et al. 
1993, Underwood \& Paterson 2003). Many benthic diatoms exhibit patterns of vertical migration which allow cells to move into the narrow photic zone present in the top few millimeters of sediment, and this diatom motility is closely linked to EPS production (Lind et al. 1997, Underwood \& Paterson 2003). The postulated role of EPS in the ecosystem includes biostabilisation of sediments (Paterson 1986), a carbon source for benthic and planktonic species (Decho 1990, Underwood \& Smith 1998a), and in mediating species interactions (Hoagland et al. 1993).

Correlations have been measured between algal biomass (chlorophyll a [chl a] concentration) and colloidal (water-soluble) carbohydrate concentrations in estuarine sediments (Underwood \& Paterson 1993, Underwood \& Smith 1998b). These observations led to the publication of a model describing the relationship between sediment chl $a$ and colloidal carbohydrate concentrations, developed using data from a number of European estuaries (Underwood \& Smith 1998b). This model has subsequently been shown to be valid in a number of other temperate and tropical intertidal and subtidal locations (Blanchard et al. 2000, van Duyl

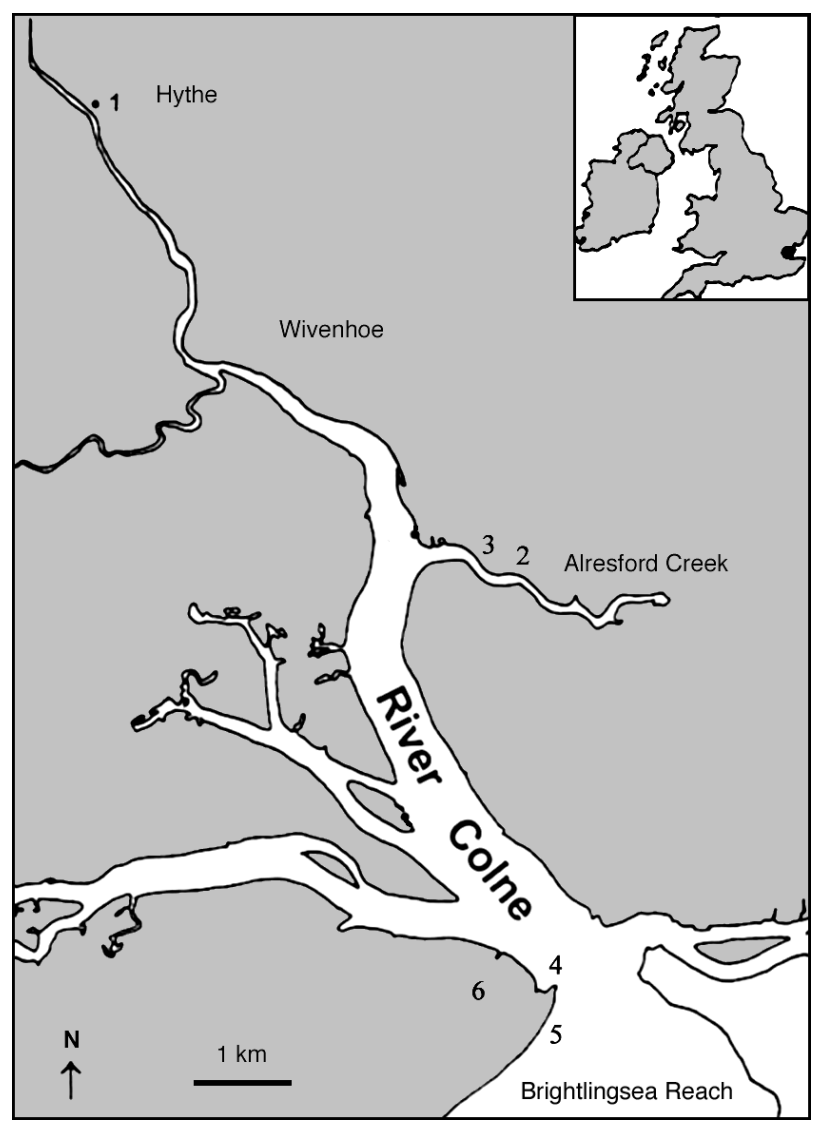

Fig. 1. Colne estuary, UK, showing locations of Sites 1 to 6 sampled in September 2002 et al. 1999, Thornton et al. 2002, Underwood 2002), indicating that it reflects a general pattern within diatom-dominated biofilms. Sediment stabilization has also been linked to colloidal carbohydrate concentration (Sutherland et al. 1998, Widdows et al. 2000a,b, Yallop et al. 2000). This has raised the possibility that sediment stability may be assessed by remote sensing of chl $a$ on the basis of the link between chl $a$ and colloidal carbohydrates (Riethmuller et al. 1998, 2000). Recent developments in our understanding of the complexity and differences in composition of benthic diatom exudates (Underwood \& Paterson 2003) indicate that it is timely to revisit the Underwood \& Smith model.

One goal of this investigation was to compare sediment carbohydrate concentrations for various carbohydrate extracts between sites of varied taxonomic composition (diatom-dominated vs. Euglena and filamentous cyanobacterial dominated) expected to fulfill the requirements of the model (Underwood \& Smith 1998b), and to determine differences in extracellular carbohydrate profiles related to location and biofilm community structure. We also looked for similarities in polymer carbohydrate composition for extracts from diverse, natural communities with those of unialgal cultures. More detailed interrogation of the sediment polymer pool is necessary as it is now clear that the rather simplistic view of sediment EPS relationships sponsored by the Underwood \& Smith model does not adequately describe the complexity and all functional aspects of different polymer groups.

Investigations of biopolymers associated with attachment and motility of common biofouling diatoms have utilized different fractionation protocols to extract the closely associated polymers (Wustman et al. 1997, Wang et al. 2000, Chiovitti et al. 2003). These protocols include use of hot water and hot bicarbonate as a means of solubilizing more complex polymers (Wustman et al. 1997, Chiovitti et al. 2003). To date, no field investigators have used this approach on natural biofilm assemblages to isolate diatom polymers. This investigation will allow for a broader comparison of cultured diatom polymers with those previously described, in addition to a direct comparison with polymers isolated from a complex community.

\section{MATERIALS AND METHODS}

Study site. Sampling was carried out at 6 sites along a salinity gradient in the Colne estuary, a mesotidal estuary that meets the North Sea on the east coast of England $\left(51^{\circ} 50^{\prime} \mathrm{N}, 1^{\circ} \mathrm{E}\right)$ (Thornton et al. 2002), over a $3 \mathrm{~d}$ period between September 11 and 16, 2002, Fig. 1). The estuary is relatively small, muddy and highly tur- 
bid (Kocum et al. 2002) and is hypernutrified due to high river inputs of nitrate and receiving $\mathrm{N}$ and $\mathrm{P}$ inputs from a wastewater treatment plant that serves Colchester discharging into the River Colne (Dong et al. 2000). Microphytobenthos are abundant in the Colne estuary, with an annual production of 25 to $1199 \mathrm{gC} \mathrm{m}^{-2} \mathrm{yr}^{-1}$ (Thornton et al. 2002, compared to a phytoplankton annual production of $8.9 \mathrm{~g} \mathrm{C} \mathrm{m}^{-2} \mathrm{yr}^{-1}$ (Kocum et al. 2002). Sites 1 to 4 were dominated by fine silts and organic matter $(<63 \mu \mathrm{m})$, typical of the inner estuarine system. Site 5 was located on the south shore of the estuary, exposed to the open sea and receiving almost no freshwater input (Fig. 1). The higher energy of the site changed the sediment type to having a greater proportion of sand but still dominated by fine silts and clays. Site 6 was located on a creek bank within the salt marsh (Fig. 1). The sediments were compacted and desiccated (during low water periods) but organically rich due to depositional processes during high water. Salinity values at the sites ranged from 5 to $20 \%$ at Site 1, 20 to $30 \%$ at Sites 2 and 3, and 30 to $34 \%$ at Sites 4 to 6 .

Sampling and carbohydrate extraction. Sediment samples were collected during daylight emersion periods (late morning to early afternoon) using Perspex core tubes (internal diameter $7 \mathrm{~cm}$ ). Ten samples were collected at each site and brought back to the laboratory for extraction. From each large core, 5 mini-core samples (internal area $3.14 \mathrm{~cm}^{2}$ ) were taken to a depth of $2 \mathrm{~mm}$. One of these was frozen $\left(-20^{\circ} \mathrm{C}\right)$, and the remaining 4 were pooled and colloidal carbohydrates immediately extracted. Species composition of biofilms was qualitatively assessed using light microscopy and high-resolution fluorescent imaging of intact biofilms (Oxborough et al. 2000).

Two protocols were utilized for isolation of materials from the sediments. Freeze-dried sediments were examined for chl a by extraction of $0.05 \mathrm{~g}$ sediment overnight with $4 \mathrm{ml}$ of cold methanol; total carbohydrates were measured from $0.01 \mathrm{~g}$ of sediment rehydrated in $1 \mathrm{ml}$ of distilled $\mathrm{H}_{2} \mathrm{O}\left(\mathrm{dH}_{2} \mathrm{O}\right)$; and extraction of colloidal carbohydrates from $0.1 \mathrm{~g}$ of sediment with $4 \mathrm{ml}$ of $25 \%$ saline solution, $1.5 \mathrm{ml}$ of which were precipitated in $3.5 \mathrm{ml}$ of cold ethanol yielding colloidal extracellular polymeric substances (cEPS) (Underwood et al. 1995). In addition, extraction of colloidal carbohydrates was carried out on non-frozen sediments immediately after return to the laboratory by adding $5 \mathrm{ml}$ of $20 \%$ saline to wet sediments at room temperature for 30 min followed by centrifugation and precipitation in $70 \% \mathrm{v} / \mathrm{v}$ cold ethanol to obtain cEPS (ethanol insoluble) and low molecular weight (LMW) (ethanol soluble) carbohydrates, which were freeze-dried for subsequent analysis. After wet extraction of colloidal carbohydrates, sediment pellets were freeze-dried and subjected to sequential extraction; $95 \%$ ethanol until supernatant was colorless, 2 water washes followed by 10 volumes $\mathrm{dH}_{2} \mathrm{O}$ at $95^{\circ} \mathrm{C}$ for $1 \mathrm{~h}$ (hot water, HW) and $0.5 \mathrm{M} \mathrm{NaHCO}_{3}$ at $95^{\circ} \mathrm{C}$ for $1 \mathrm{~h}$ (hot bicarbonate, HB) (Wustman et al. 1997). These extracts were dialyzed against water (6 to 8000 Da cut-off) and freeze-dried in preparation for carbohydrate analysis. Experiments were also carried out using lens tissue containing diatoms. Two layers of lens tissue were spread out over surface biofilms during low tide and left for $\sim 1 \mathrm{~h}$ to allow motile diatoms to migrate into the top layer (Eaton \& Moss 1966). These sheets were freeze-dried and sequentially extracted as above. As a control, lens tissue that had not been exposed to diatoms was extracted in a similar manner and detected sugars were subtracted from the experimental results.

Diatom cultures. Nitzschia epithemioides Grunow in Cleve et Grunow, Navicula phyllepta Kutzing and Cylindrotheca closterium (Ehrenb.) Reimann et Lewin were isolated from the Colne estuary by the lens tissue method (Eaton \& Moss 1966) and maintained in natural seawater with $\mathrm{f} / 2$ enrichment at $18^{\circ} \mathrm{C}$ at a light intensity of $\sim 100 \mu \mathrm{mol} \mathrm{m} \mathrm{m}^{-2} \mathrm{~s}^{-1}$ on a 12:12 h light:dark cycle. Axenic cultures were established by treating with erythromycin, penicillin, and kanomycin (each at a concentration of $3 \mathrm{mg}$ per $100 \mathrm{ml} \mathrm{f/2).}$

Cultures were sequentially extracted by a slight modification of methods described above. Briefly, after cultures had reached stationary growth, cells were isolated from growth media which was dialyzed against a 6 to 8000 Da filter to remove salts and LMW materials. A portion of this material was freeze-dried for analysis (colloidal fraction) and the remaining amount was precipitated in cold ethanol overnight to yield the cEPS fraction. Ethanol-insoluble material was rinsed 3 times in ethanol and re-suspended in $\mathrm{dH}_{2} \mathrm{O}$ prior to lyophilization (Underwood et al. 2004). Cell pellets were sequentially extracted as above for HW and HB fractions (Wustman et al. 1997). cEPS data for Cylindrotheca closterium was obtained using similar protocols at different growth phases by Underwood et al. (2004).

Carbohydrate analysis. Carbohydrate concentrations were determined using the phenol/sulfuric acid assay (Dubois et al. 1956) with glucose as the standard. Uronic acids were detected with the carbazole assay (Bitter \& Muir 1962) with glucuronic acid as the standard. Monosaccharide analysis was performed as described by Wustman et al. (1997) with identification/quantitation of alditol acetates by gas chromatography/mass spectrometry. Quantitation was based on response factors derived from injections of standards that had undergone the same hydrolytic procedures (Wustman et al. 1997). Monosaccharide composition was not determined for cEPS from Nitzschia epi- 
themioides and lens tissue or from the lens tissue HB fraction due to low carbohydrate concentrations.

Statistical analysis. Comparisons between sites were made using 1-way ANOVA on log-transformed data followed by Tukey's honestly significant difference (HSD) test to detect differences between sites. One-way ANOVAs to determine differences between sites for the percentages of colloidal carbohydrate and cEPS carbohydrate were carried out on arcsine- transformed data (Zar 1999) using Systat v. 10. For comparison with the Underwood \& Smith model, sediment chl $a$ and sediment carbohydrate data were log $(\mathrm{N}+1)$ transformed. Principal component (PCA) and cluster analyses of the percentage similarity of monosaccharide profiles of the different carbohydrate fractions were calculated using un-weighted pair-group averaging (MVSP v. 3.13b, 2002, Kovac Computing Services).
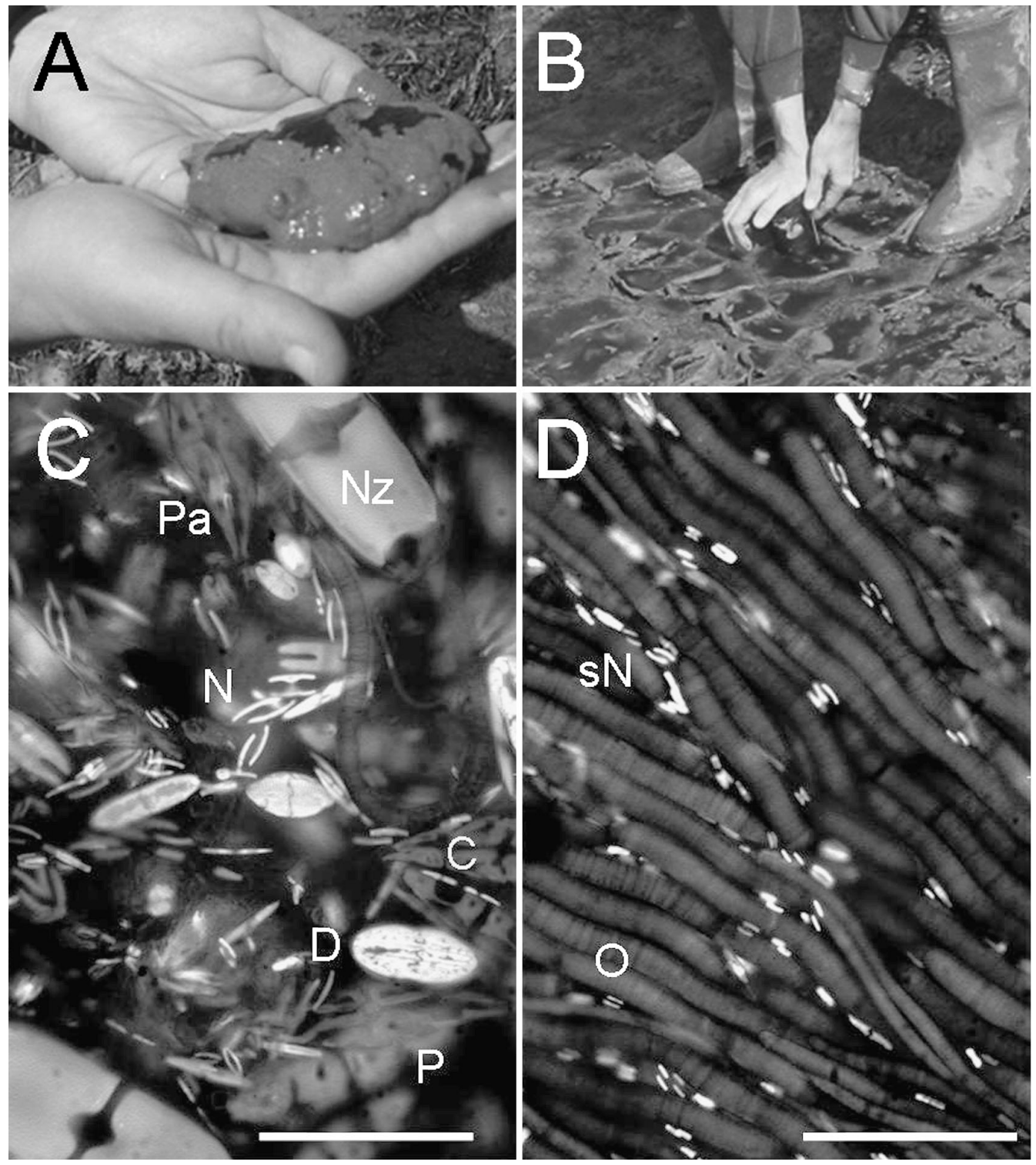

Fig. 2. (A) Sediment from Site 2, showing the dense biofilm (dark patches) and the underlying pale sediment. (B) Cyanobacterial mats (Site 6). Note the firm nature of the sediment and the pattern of desiccation breccias dissecting the mats. (C) High resolution-fluorescent image of an intact biofilm from Site 3. Individual diatoms are visible due to autofluorescence of their chloroplasts: $\mathrm{Nz}=$ Nitzschia dubia W. Sm; Pa = Pleurosigma angulatum (Quekett) W. Sm; N = Navicula phyllepta Kütz; C = Cylindrotheca signata Reimann \& Lewin; D = Diploneis didyma (Ehren.) Cleve; P = Plagiotropis vitrea (W. Smith) Kuntze. (D) High resolutionfluorescent image of cyanobacterial mats from Site 6. Individual trichomes of Oscillatoria are visible (O) with small Navicula species (sN) between. Scale bars $(\mathrm{C}, \mathrm{D})=40 \mu \mathrm{m}$ 


\section{RESULTS}

\section{Community descriptions}

Sites 1 to 5 were dominated by benthic diatoms (>50\% relative abundance at Sites 1 to 4 ), though at Site 5 euglenophytes were also abundant. These 5 sites all supported abundant biofilms at the surface of the soft sediment (Fig. 2A). Species richness was high, with many Navicula (mainly N. phyllepta), Diploneis, Cylindrotheca, Gyrosigma (G. limosum, G. fasciola) and Pleurosigma species present, and species abun- dances and distributions were similar to those previously observed in the Colne estuary (Fig. 2C) (Underwood et al. 1998, Thornton et al. 2002). Chl a concentrations were significantly different among Sites 1 to 6 ( $p<0.001)$. Values ranged from $2.7 \pm 0.6 \mu \mathrm{g} \mathrm{cm}^{-2}$ (SE) at Site 5 to $25.97 \pm 2.50 \mu \mathrm{g} \mathrm{cm}^{-2}$ at Site 3. Sites 1, 2 and 4 had chl a concentrations between 9 and $13 \mu \mathrm{g} \mathrm{cm}$ (Fig. 3A). Chl a concentrations at Site 5 were significantly lower than at all other sites. Site 6 was a thick $(1 \mathrm{~cm})$ cyanobacterial mat, located within a saltmarsh creek (Fig. 2B). This cyanobacterial mat had significantly higher chl a concentrations than the other sites $\left(51.51 \pm 12.64 \mathrm{mg} \mathrm{cm}^{-2}\right)$. Though the majority of the biomass consisted of cyanobacterial trichomes (predominately Oscillatoria sp.), fluorescent imaging of intact biofilms revealed the presence of many small naviculoid diatoms (primarily N. phyllepta) amongst the cyanobacterial filaments (Fig. 2D)

\section{Carbohydrate concentrations}

The cyanobacterial mats at Site 6 had significantly higher concentrations of total and colloidal carbohydrates and cEPS than all the other intertidal biofilms. Total carbohydrate content values at Sites 1 to 5 ranged from $970 \pm 134.5$ to $1298 \pm 124.5 \mathrm{mg}$ $\mathrm{cm}^{-2}$ of sediment (Fig. 3A) and Site 6 had a total carbohydrate content of $3195 \pm 548.8 \mathrm{mg} \mathrm{cm}^{-2}$. cEPS values for Sites 1 to 5 were between $19.0 \pm 4.8$ and $64.0 \pm 22.5 \mu \mathrm{g} \mathrm{cm} \mathrm{cm}^{-2}$ (Fig. 3C). When total carbohydrates and cEPS were compared among Sites 1 to 6, significant variations $(p<0.001)$ were observed, with most differences found when compare to Site 6. Colloidal carbohydrates for Sites 1 to 5 varied from $99.7 \pm 21.3$ to $220.6 \pm 36.2 \mu \mathrm{g} \mathrm{cm}^{-2}$. Significant differences were observed among all sites for colloidal carbohydrates ( $p<0.001)$, but these were only due to the significantly higher values at Site 6, with Sites 1 to 5 not differing significantly ( $p>0.05$ ) (Fig. 3B).

Ratios of carbohydrate concentrations to biomass (expressed as $\mu \mathrm{g} \mathrm{\textrm {cm } ^ { - 2 }}$ chl a) were compared among sites and fractions. Sites 1 to 4 were generally similar but Site 5 dominated the values
Fig. 3. Chl a concentrations ( $\bullet$ in $A$ ) and (A-C) sediment carbohydrate concentrations and (D-F) carbohydrates expressed as a ratio to chl a from the top $2 \mathrm{~mm}$ of sediment for sites sampled within the Colne estuary, UK, in September 2002. $n=10$, except for Site 1 where $n=8$. Standard errors shown. Sites not significantly different from each other are coded with the same letters. cEPS: colloidal extracellular polymeric substances 

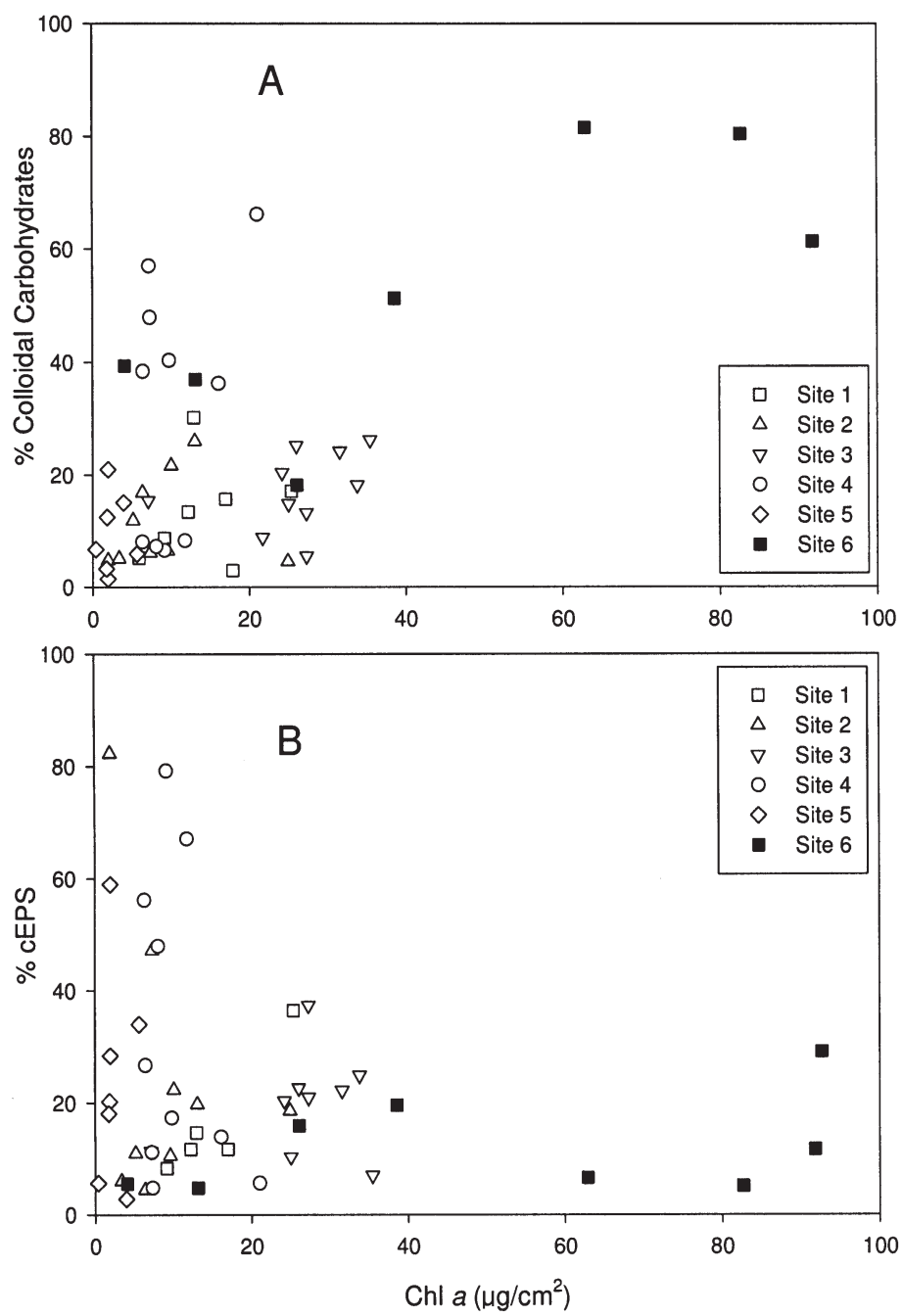

Fig. 4. Percentages of (A) colloidal carbohydrates in the sediment and (B) the cEPS portion of the colloidal carbohydrates for all sites sampled from the Colne estuary, UK. $\mathrm{n}=58$

because of the low chl a concentrations present (Fig. 3D-F). Total carbohydrate:chl a ratios ranged from $52.9 \pm 4.9$ to $474.5 \pm 79.5$ (Fig. 3D). Colloidal carbohydrate:chl a ratios varied for Sites 1 to 5 from $8.6 \pm 1.1$ to $46.5 \pm 16.0$ (Fig. 3E). The ratio of cEPS to chl a ranged from $2.3 \pm 0.7$ to $14.1 \pm 9.2$ (Fig. 3F), with values for Site 5 being 2 to 5 times as large as those for Sites 1 to 4 . Significant differences in carbohydrate:chl a among Sites 1 to 5 were observed for total and colloidal carbohydrates $(\mathrm{p}<0.001)$, while cEPS:chl a was only slightly significant $(p<0.05)$ (Fig. 3D-F). Site 6 had the greatest biomass present but also had the largest ratio of colloidal carbohydrates compared to Sites 1 to 5 (Fig. 3E). Diatom-dominated sites were equivalent in carbohydrate:chl a ratios, with variation occurring when compared with Sites 5 and 6 (Fig. 3E,F).
The percentage of colloidal carbohydrates in the total carbohydrate fraction varied significantly $(\mathrm{p}<$ 0.001 ) among Sites 1 to 6 , with values of $10.7 \pm 2.4 \%$ to $29.0 \pm 7.1 \%$. Site 6 was dramatically higher (nearly double with $42.5 \pm 8.9 \%$ colloidal carbohydrates). Site 5 had a very small portion of its total carbohydrate concentration represented in the soluble carbohydrate fraction $(10.7 \pm 0.3 \%)$. The percentage of cEPS within the colloidal carbohydrate pool was not significantly different among Sites 1 to $6(\mathrm{p}=0.366)$. Values ranged from $15.5 \pm 5.7$ to $30.3 \pm 8.6 \%$ for cEPS. Proportions of cEPS were comparable at Site $6(12.9 \pm 3.3 \%)$, though absolute concentrations were higher (see Fig. 4 for all percent data values). The percent colloidal carbohydrate relative to the total sediment carbohydrate and the percent of colloidal carbohydrate as cEPS both showed a significant inverse relationship with chl $a$ concentration. The former increased with increasing biomass while the latter decreased (Fig. 4A \& B, respectively). Variability was far higher at low chl a concentrations.

\section{Underwood \& Smith model}

Sites 1 to 5 were the best fit to the criteria of the Underwood \& Smith model and were analyzed by regression to look for positive correlations between the concentration of colloidal carbohydrates and chl $a$ and cEPS vs. chl a. There were significant correlations between sediment colloidal carbohydrate and chl $a$ content $\left(\mathrm{r}^{2}=24.9 \%\right)$ and $\mathrm{cEPS}$ and chl a content $(39.2 \%)$ (Fig. 5). The slope and intercept of the colloidal carbohydrate:chl a relationship were significantly different from zero $(p<0.001)$ and the slope and intercept of the cEPS varied significantly from zero $(\mathrm{P}<$ 0.001). No relationship was observed between total carbohydrates and chl a (coefficient of correlation = $1 \%$, data not shown). Comparisons of the slopes derived here with that of the Underwood \& Smith model showed no significant differences for both the colloidal carbohydrates and cEPS $\left(t_{0.05(2), 74}=0.253, \mathrm{p}>\right.$ 0.50 and $t_{0.05(2), 74}=0.295, \mathrm{p}>0.50$, respectively).

\section{Monosaccharide analysis}

Eight neutral sugars were identified: rhamnose (rha), fucose (fuc), ribose (rib), arabinose (ara), xylose (xyl), mannose (man), galactose (gal), and glucose (glc). Cluster analysis grouped sites and species into 6 groups at the $70 \%$ similarity level based on monosaccharide distributions within fractions (Table 1). Group 5 was composed of HW extracts from cultured diatoms and from lens tissue and was defined by sig- 
nificantly more glc compared with all other fractions ( $p<0.05$ ). Group 6 primarily consisted of LMW carbohydrates, cEPS and HW extracts from field and culture organisms and was significantly enriched in glc compared with Groups 1 to $4(\mathrm{p}<0.05)$ (Table 1). These 2 groups cluster along the glc vector (Fig. 6). cEPS from Cylindrotheca closterium clustered in Groups 4, 5 and 6 (Table 1) and aligned more along the glc, man and xyl vectors (Fig. 6). HB from field and all diatom cultures were the major components of Groups 2 and 3 and clustered along the rha and fuc vectors (Fig. 6) and were significantly enriched in rha and fuc compared with Groups 4 to 6 ( $\mathrm{p}<0.05$ ) (Table 1). Groups 1 and 2 clustered along the gal and ara vectors (Fig. 6). Group 2 was significantly
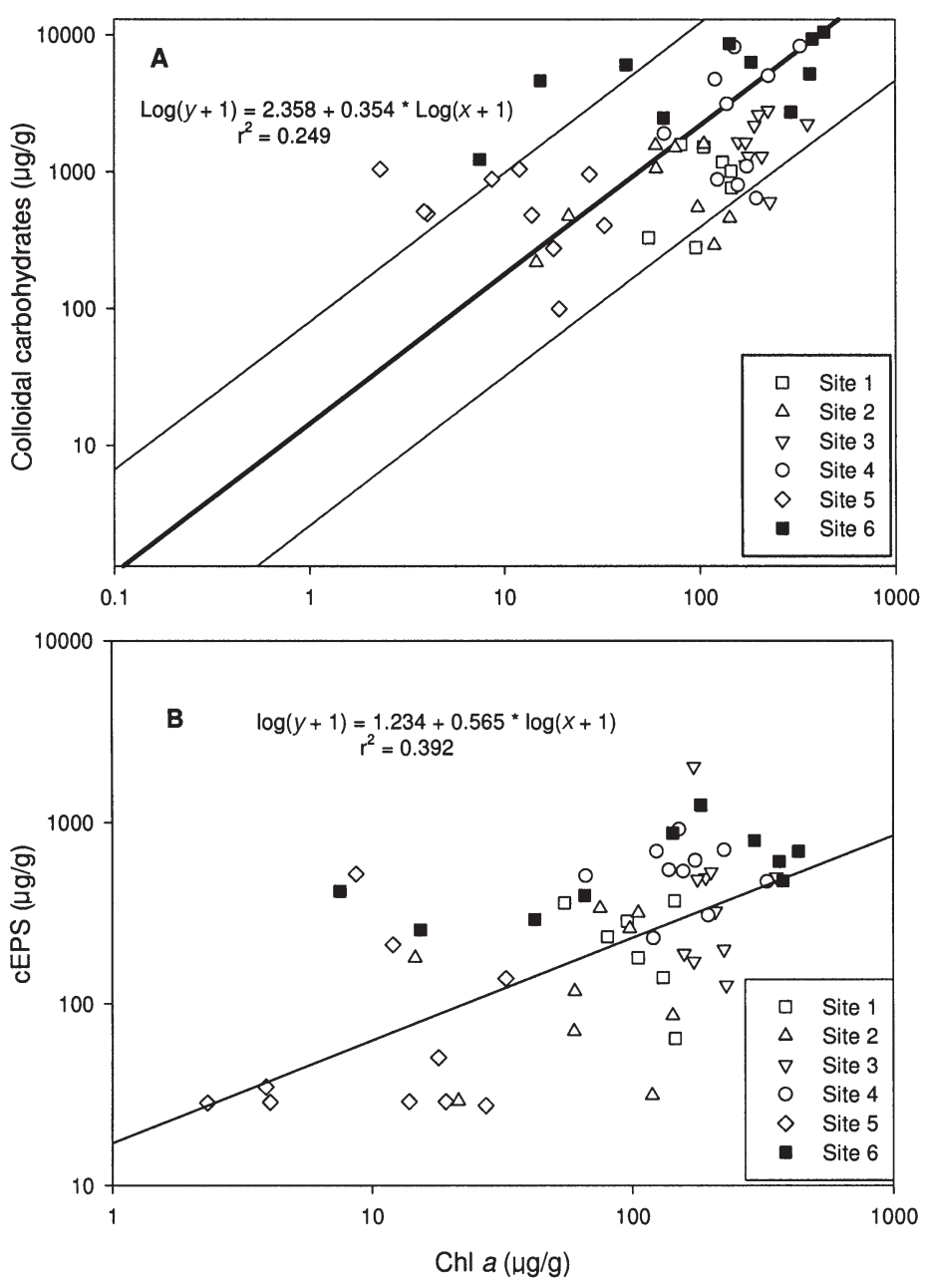

Fig. 5. Relationship between (A) colloidal carbohydrates and chl $a$ and (B) cEPS and chl $a$ for all sites sampled from the Colne estuary, UK, in September 2002. Regression lines and equations were generated from $\log (\mathrm{N}+1)$ transformed data and apply to Sites 1 to 5 that best fit the requirements of the Underwood \& Smith model. $\mathrm{n}=46$ for Sites 1 to 5 , and $\mathrm{n}=10$ for Site 6

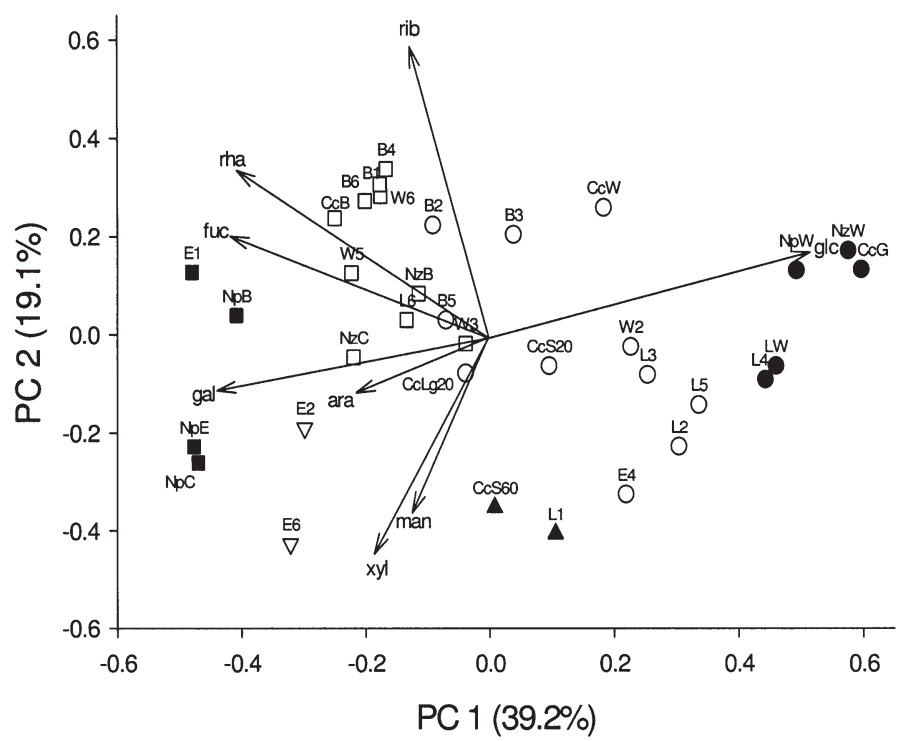

Fig. 6. Principal component analysis scatter plot grouping monosaccharide profiles of samples along dominant sugar vectors. Symbols indicate the different groupings derived from the cluster analysis, see Table 1 for details. C: colloidal; E: cEPS; L: low molecular weight (LMW); LW: lens tissue hot water $(\mathrm{HW}) ; \mathrm{W}$ : HW; B: hot bicarbonate $(\mathrm{HB}) ; \mathrm{Np}$ : Navicula phyllepta; Nz: Nitzschia epithemioides; Cc: Cylindrotheca closterium

enriched in gal compared with Groups 3, 5 and 6 (p < $0.05)$, and Group 1 was significantly enriched in ara compared with groups Groups 3, 5 and $6(\mathrm{p}<0.05)$ (Table 1, Fig. 6). The monosaccharide distributions of cEPS showed high variability and no data were available for Sites 3 and 5 due to lack of material (Table 1). Colloidal and cEPS from cultured species were closely related to the HB fraction (Table 1). Navicula phyllepta colloidal carbohydrates and cEPS had nearly identical monosaccharide distribution profiles despite absolute carbohydrate concentrations of cEPS being $\sim 20 \%$ of the colloidal total. The N. phyllepta monosaccharide culture data were clustered with the EPS profiles from Site 1, where the microphytobenthos assemblage comprised between 50 and $65 \%$ N. phyllepta (M. Barnett \& G. J. C. Underwood unpubl. obs.).

\section{Uronic acids}

All cEPS fractions analyzed showed less than 1\% uronic acids (Table 1). HW and HB extracts yielded the largest percentage $(\mathrm{w} / \mathrm{w})$ of uronic acids detected (Table 1). HW from sites 2 and 3 had the highest uronic acid content, both with nearly $10 \%$ of the polymer mass as uronic acids. HB from Sites 2 and 5 had the greatest proportions of uronic acids $(7.5$ and $8.9 \%$, 
Table 1. Monosaccharide distributions of extracts from sites within the Colne estuary, UK, and for 3 cultured diatoms Cylindrotheca closterium, Navicula phyllepta, and Nitzschia epithemioides ( $=6$ for Site 2 and $n=3$ for Sites 3, 5 and 6 HW (hot water); $\mathrm{n}=3$ for HB (hot bicarbonate) $\mathrm{n}=1$ for the LMW (low molecular weight) and cEPS (colloidal extracellular polymeric substances); $N$. phyllepta, and C. closterium $\mathrm{n}=3$ for colloidal, cEPS, HW and HB extracts and $\mathrm{n}=6$ for $N$. epithemioides). cEPS monosaccharide profiles for logarithmic (LG) and stationary (S) phase of C. closterium growth from Underwood et al. (2004). Uronic acids were expressed as \% (w/w). Symbol column refers to cluster grouping, based on $>70 \%$ similarity in monosaccharide composition. Variability within sample replicates less than 5\% (where applicable). ND: not detected; $-:$ no data (indicates insufficient material for analysis). Rha: rhamnose; Fuc: fucose; Rib: ribose; Ara: arabinose; Xyl: xylose; Man: mannose; Gal: galactose; Glc: glucose

\begin{tabular}{|c|c|c|c|c|c|c|c|c|c|c|c|c|}
\hline \multirow[t]{2}{*}{ Extract } & \multirow[t]{2}{*}{ Site/Species } & \multicolumn{8}{|c|}{ Monosaccharide (expressed as \% of total detected sugar) } & \multirow[t]{2}{*}{ Cluster } & \multirow[t]{2}{*}{ Symbol } & \multirow{2}{*}{$\begin{array}{l}\text { Uronic acids } \\
\text { (\% of weight) }\end{array}$} \\
\hline & & Rha & Fuc & Rib & Ara & $\mathrm{Xyl}$ & Man & Gal & Glc & & & \\
\hline \multirow[t]{3}{*}{ Colloidal } & Nitzschia epithemiodes & 13.7 & 7.7 & 1.6 & 8.6 & 12.4 & 17.0 & 15.4 & 23.6 & 3 & $\square$ & - \\
\hline & Navicula phyllepta & 10.4 & 12.9 & 0.1 & 1.3 & 23.2 & 15.3 & 32.6 & 4.2 & 2 & $\boldsymbol{\square}$ & - \\
\hline & Cylindrotheca closterium & - & - & - & - & - & - & - & - & - & - & - \\
\hline \multirow[t]{12}{*}{ cEPS } & 1 & 13.0 & 26.5 & ND & 7.4 & 5.3 & 10.6 & 20.4 & 16.9 & 2 & $\mathbf{\square}$ & 0.4 \\
\hline & 2 & 5.8 & 8.6 & ND & 37.2 & 9.0 & 8.6 & 19.1 & 11.7 & 1 & $\nabla$ & 0.9 \\
\hline & 3 & - & - & - & - & - & - & - & - & - & - & - \\
\hline & 4 & 2.0 & 3.4 & ND & 1.3 & 33.0 & 6.4 & 3.0 & 50.9 & 6 & O & 0.1 \\
\hline & 5 & - & - & - & - & - & - & - & - & - & - & - \\
\hline & 6 & 4.5 & 6.5 & ND & 24.9 & 26.9 & 11.8 & 21.3 & 4.4 & 1 & $\nabla$ & Trace \\
\hline & Nitzschia epithemiodes & - & - & - & - & - & - & - & - & - & - & - \\
\hline & Navicula phyllepta & 10.9 & 12.8 & 0.0 & 5.1 & 22.3 & 11.8 & 32.5 & 4.5 & 2 & $\mathbf{\square}$ & - \\
\hline & Cylindrotheca closterium $\mathrm{G}$ & 2.0 & 2.0 & 0.0 & 0.0 & 2.0 & 0.0 & 0.0 & 94.0 & 5 & - & - \\
\hline & Cylindrotheca closterium LG20 & 9.0 & 6.5 & 0.0 & 0.0 & 12.1 & 11.1 & 19.9 & 41.2 & 6 & 0 & - \\
\hline & Cylindrotheca closterium S20 & 7.0 & 4.9 & 0.0 & 0.0 & 10.1 & 10.0 & 16.8 & 51.4 & 6 & O & - \\
\hline & Cylindrotheca closterium S60 & 0.0 & 0.0 & 0.0 & 0.0 & 0.0 & 34.1 & 33.0 & 32.0 & 4 & $\Delta$ & - \\
\hline \multirow[t]{6}{*}{ LMW } & 1 & 5.7 & 1.8 & ND & ND & 18.3 & 34.5 & 3.6 & 36.1 & 4 & $\Delta$ & - \\
\hline & 2 & 3.0 & 1.6 & ND & ND & 11.9 & 22.5 & 3.0 & 58.0 & 6 & O & - \\
\hline & 3 & 6.6 & 3.4 & ND & 1.7 & 8.7 & 15.8 & 4.0 & 59.7 & 6 & O & - \\
\hline & 4 & 1.4 & 0.9 & ND & 0.6 & 7.6 & 12.2 & 3.5 & 74.0 & 5 & $\bullet$ & - \\
\hline & 5 & 3.5 & 2.0 & ND & ND & 11.0 & 16.0 & 3.5 & 64.1 & 6 & O & - \\
\hline & 6 & 17.5 & 10.4 & ND & 2.7 & 10.1 & 16.5 & 7.3 & 35.5 & 3 & $\square$ & - \\
\hline \multirow[t]{10}{*}{ HW } & 1 & - & - & - & - & - & - & - & - & - & - & - \\
\hline & 2 & 3.3 & 2.8 & 0.6 & 4.8 & 4.7 & 8.4 & 10.2 & 48.6 & 6 & O & 10.0 \\
\hline & 3 & 5.7 & 5.0 & 3.7 & 18.8 & 6.7 & 18.1 & 15.4 & 44.7 & 3 & $\square$ & 9.8 \\
\hline & 4 & - & - & - & - & - & - & - & - & - & - & - \\
\hline & 5 & 10.4 & 11.1 & 3.3 & 17.8 & 5.0 & 11.2 & 18.1 & 32.9 & 3 & $\square$ & 5.8 \\
\hline & 6 & 16.1 & 12.7 & 3.7 & 2.0 & 7.0 & 8.9 & 12.3 & 37.4 & 3 & $\square$ & 4.4 \\
\hline & Lens tissue & 1.3 & 0.8 & 0.6 & 0.0 & 15.6 & 2.9 & 2.4 & 76.5 & 5 & $\bullet$ & - \\
\hline & Nitzschia epithemiodes & 0.9 & 0.4 & 2.3 & ND & 0.8 & 2.0 & 3.3 & 90.3 & 5 & $\bullet$ & 21.1 \\
\hline & Navicula phyllepta & 0.9 & 2.9 & 2.1 & 1.1 & 2.6 & 2.9 & 3.3 & 84.0 & 5 & $\bullet$ & 10.9 \\
\hline & Cylindrotheca closterium & 8.6 & 1.8 & 6.0 & 1.1 & 4.4 & 13.3 & 7.4 & 57.4 & 6 & O & - \\
\hline \multirow[t]{9}{*}{ HB } & 1 & 12.2 & 10.3 & 6.4 & 5.1 & 5.6 & 11.3 & 15.7 & 33.5 & 3 & $\square$ & 3.8 \\
\hline & 2 & 10.7 & 10.0 & 5.02 & 4.23 & 8.0 & 10.9 & 13.7 & 42.1 & 6 & O & 7.5 \\
\hline & 3 & 7.9 & 6.9 & 4.7 & 3.8 & 6.1 & 9.1 & 13.7 & 49.5 & 6 & O & 4.3 \\
\hline & 4 & 9.8 & 9.3 & 8.13 & 5.8 & 6.3 & 10.6 & 18.6 & 35.6 & 3 & $\square$ & 4.1 \\
\hline & 5 & 11.1 & 10.1 & ND & 4.9 & 5.7 & 11.5 & 16.0 & 42.3 & 6 & 0 & 8.9 \\
\hline & 6 & 11.7 & 9.7 & 7.3 & 5.4 & 8.9 & 13.6 & 14.5 & 28.6 & 3 & $\square$ & 7.1 \\
\hline & Nitzschia epithemiodes & 10.7 & 9.6 & 2.7 & ND & 10.3 & 15.4 & 15.2 & 36.2 & 3 & $\square$ & 6.0 \\
\hline & Navicula phyllepta & 16.6 & 10.5 & 4.1 & 4.4 & 19.6 & 13.9 & 19.7 & 11.2 & 2 & $\mathbf{\square}$ & 6.0 \\
\hline & Cylindrotheca closterium & 20.2 & 3.9 & 6.3 & ND & 13.7 & 12.2 & 17.7 & 26.2 & 3 & $\square$ & - \\
\hline
\end{tabular}

respectively). No HW extract data were available for Sites 1 and 4 because of a lack of material. The HW fraction had the highest uronic acid content in both Navicula phyllepta (21\%) and Nitzschia epithemioides $(10.9 \%)$ while the HB for both species was $6 \%$ (Table 1). Uronic acid content data for Cylindrotheca closterium were not available.

\section{DISCUSSION}

Significant differences in both biomass and the relative proportions of different carbohydrate fractions between biofilms from different sites in the Colne estuary were observed. Biomass differences among sites reflect the many variables (nutrients, disturbance, 
grazing etc.) that influence biomass in intertidal sediments (Underwood \& Kromkamp 1999). Despite this wide biomass range, the Underwood \& Smith model showed a good fit for the relationship between colloidal carbohydrate and sediment chl a content among Sites 1 to 5. It has been shown that diatoms, cyanobacteria, bacteria and euglenoids produce extracellular carbohydrates for a number of functions, including motility, biofilm formation and substratum adhesion (Hoagland et al. 1993, Underwood \& Paterson 2003). Fractionation protocols currently used probably have not isolated polymers with unique properties within the biofilm, rather they represent a mixture of polymers and though we do not know how selective current fractionation protocols are, these techniques have been shown to have ecological utility with respect to sediment stability or relationships with microphytobenthic biomass and production (Underwood \& Paterson 2003). The level of correlation between the colloidal carbohydrates:chl a data presented in this paper was not as high as observed in other studies (Underwood \& Smith 1998b). A possible explanation is the restricted range of values (between 1 and 1.5 orders of magnitude) compared to the 3 orders of magnitude over which the original model was constructed. However, the majority of the data fall within the $95 \%$ prediction limits of the Underwood \& Smith (1998b) model. Thornton et al. (2002) found that comparing single site data did not always show a significant correlation, whereas pooled data along a whole estuary over a 1 yr period was correlated. Colloidal carbohydrates:chl a for the cyanobacterial mat did not fit the model, with sediment carbohydrate and cEPS content independent of chl a content. This fits the prediction of Underwood \& Smith (1998b) and may reflect the different balance of carbohydrate components and different sugar composition of the fractions isolated from these mats.

With increasing chl a concentration there was a corresponding increase in colloidal carbohydrate as a percentage of the total carbohydrates (with the exception of Site 5), which indicates the important contribution of microalgal exudates to the total sediment carbohydrate pool. As biomass increased, however, the cEPS component of the colloidal fraction decreased, from approximately 40 to $10-20 \%$ in diatom-rich biofilms at high biomass. The decreasing predominance of cEPS within the colloidal fraction as biomass increases has also been reported in biofilms from the Severn estuary (Yallop et al. 2000), with about 20\% cEPS within the colloidal fraction at higher biomass. The decrease in the proportion of cEPS is a consequence of greater amounts of LMW carbohydrate production. Production of LMW compounds is closely associated with photosynthesis (Smith \& Underwood 1998, 2000, Staats et al.
2000, de Brouwer \& Stal 2001, Perkins et al. 2001 Underwood 2002) and this material had a high glucose content (Table 1) which distinguishes it from sediment cEPS but not from some of the culture cEPS. de Brouwer \& Stal (2001) showed that the glucose content of a range of size classes, including the $<1 \mathrm{kDa}$ fraction, increased during periods of photosynthesis and was glucose rich. Given that $70 \%$ of colloidal carbohydrates are LMW, it is not surprising that Taylor et al. (1999) observed that colloidal carbohydrate contained $>80 \%$ glucose. The changes in relative proportions and composition of the extracellular carbohydrates as algal biomass changes indicate that the linear colloidal carbohydrates:chl a relationship (as often reported, and predicted by the Underwood \& Smith model) may conceal a significant shift in the potential properties of the carbohydrate pool.

Photosynthetic activity should also stimulate intracellular glucan production (Underwood et al. 2004). Extracting with warm and hot water has been shown to be effective in liberating the intracellular storage glucan chrysolaminarin (Ford \& Percival 1965, Allan et al. 1972, Wustman et al. 1997, Chiovitti et al. 2003, 2004). Extracting with warm water has been reported not to induce cell lysis (Staats et al. 1999, de Brower \& Stal 2002); however, Chiovitti et al. (2004) has demonstrated that the glucose is derived primarily from intracellular sources. Colne estuary HW fractions showed glucose enrichment as did HW from unialgal cultures. HW from lens tissue containing motile diatoms also showed a high glucose content, corroborating the evidence that high glucose yield is partly due to intracellular glucan. No investigations to date have shown a large intracellular polysaccharide in diatoms aside from the glucan chrysolaminaran. All of the HW fractions were a part of 2 distinct clusters (Table 1, Fig. 6) and their glucose dominance was evident with grouping along the glc vector in the PCA (Fig. 6).

In an attempt to isolate polymers with unique chemistry and functions from a system, investigators have applied sequential extraction protocols to sediments and cultures (ex. EDTA, alkali, bicarbonate) (Hoagland et al. 1993, Wustman et al. 1997, de Brouwer et al. 2003). We determined that HB would release tightly bound polymers from unialgal cultures of mudflat diatoms. We have observed that sequential extraction as applied here to sediments (yielding the HW and HB fractions) can liberate $>30 \%$ of the total carbohydrate pool remaining after colloidal carbohydrate extraction (B. J. Bellinger unpubl. data). The HB fraction comprised clusters 2 and 3 (Table 1) and grouped along the rha and fuc components (Fig. 6). Enrichment in the proportions of rha and fuc has been correlated with increased surface reactivity in marine transparent exopolymers (Zhou et al. 1998). de Brouwer et al. 
(2003) observed similarities in monosaccharide composition in EDTA extracts of tightly bound materials from sediments of 3 European estuaries and also from compositional work on open ocean DOM (Borch \& Kirchmann 1997).

Monosaccharide profiles of un-fractionated sediments showed greater amounts of rha, gal, xyl and fuc in the bulk carbohydrate fraction compared to the glucose-rich colloidal fraction (Taylor et al. 1999). These monosaccharides (rha, gal, xyl, fuc) were enriched in the HB fraction of Pinnularia viridis (Nitzsch) and in the $\mathrm{HB}$ fraction of the sediments sampled here. The HB fraction was xylose enriched, most notably in Nitzschia epithemioides and Cylindrotheca closterium in agreement with results from $P$. viridis and in the mechanically isolated stalks of Cymbella cistula (Ehr.) and C. mexicana (Ehr.), both freshwater stalk formers (Wustman et al. 1997, Chiovitti et al. 2003). Using atomic force microscopy in correlation with sequential extraction, Chiovitti et al. (2003) observed that the HB polymers were gelatinous and detachment of $N$. epithemioides cells from glass slides has been observed only after the addition of hot $0.5 \mathrm{M} \mathrm{NaHCO}_{3}$ (B. J. Bellinger pers. obs.). Colloidal carbohydrates and cEPS from cultured diatoms and a few field cEPS clustered with HB and may indicate sloughing and solubilization of tightly bound materials as the biofilm ages (i.e. reaches stationary phase). Chiovitti et al. (2003) also observed a close relationship between monosaccharides of $\mathrm{HB}$ and the spent culture medium (SCM which was the portion of the media $>5 \mathrm{kDa}$ membrane), making SCM analogous to the colloidal fraction described here.

The complexity of the HW and HB fractions is further indicated by high uronic acid content (3 to $10 \%$ of total weight). In both the field and culture material, HW had the highest percentage of uronics. These data are in agreement with values obtained from materials isolated from diatom culture (Wustman et al. 1997) and in field studies (Underwood et al. 1995). In comparison, cEPS had a uronic acid content of less than $1 \%$. These acidic groups provide additional sites for ionic crosslinking providing potential sites sediment-organism interaction with the biofilm. Yallop et al. (2000) showed a positive correlation between sediment stability and colloidal carbohydrates (saline soluble) but not between EDTA-soluble materials. The importance of colloidal carbohydrates influencing sediment properties have also been shown by numerous other researchers (Paterson 1989, Underwood \& Paterson 1993, van Duyl et al. 1999).

The potential for more tightly bound polymers to persist in the environment and resist degradation was demonstrated by van Duyl et al. (2000), who were unable to correlate bacterial activities with EDTAsoluble extracts from the Ems-Dollard estuary. Col- loidal carbohydrates do appear more available to bacteria, with LMW material being the most preferentially utilized (van Duyl et al. 2000). Giroldo et al. (2003) found that bacteria preferentially degraded the glucose portions of polymers over the fucose and rhamnose regions produced by planktonic diatoms.

Correlations between sediment carbohydrate dynamics and uni-algal polymer production have typically been done using carbohydrate content. Underwood \& Paterson (2003) used cluster analysis to compare data collected from a wide variety of culture and field experiments, but found inconsistencies in groupings, probably due to variations in methodologies in polymer isolation and characterization. This study used a consistent set of extraction protocols applied uniformly to field and cultured species which were based on protocols that have ascribed functionality in previous investigations. HW and HB extract more tightly bound polymers that have been shown to aid diatoms in attachment, motility and encasing the frustule. The multivariate analysis of monosaccharide profiles showed similarities between polymers isolated from culture and those extracted from complex, diverse benthic assemblages. The exact relationship between sediment carbohydrate fractions isolated from diatom-rich biofilms and those produced in diatom cultures is not clear, but the close agreement between monosaccharide profiles of certain N. phyllepta culture fractions and a biofilm dominated by $N$. phyllepta indicates that in certain circumstances the relationship may be close. The potential for modification through cross-linking, degradation, production, etc. of diatom EPS in the environment (by both biological and physical processes) is potentially large, though as yet undemonstrated. Estuarine diatoms produce different types of EPS in response to varying conditions (de Brouwer \& Stal 2001, Perkins et al. 2001, Underwood et al. 2004) and the close relationship between diatom biomass and sediment carbohydrate fractions indicates that diatom exudates are an important source of carbohydrate material in sediments. It will be necessary to determine the structure and properties of these different EPS to determine their potential role(s) in sediment stabilization and food chain dynamics within estuarine sediments.

Acknowledgements. This work was funded by NSF grant IBN-0110875 to MRG and GJCU and NERC GRANT NER/A/ S/2001/00536 to GJCU. We would also like to acknowledge the comments of 3 anonymous reviewers for strengthening this manuscript.

\section{LITERATURE CITED}

Allan GG, Lewin J, Johnson PG (1972) Marine polymers. IV. Diatom polysaccharides. Bot Mar 15:102-108 
Bitter T, Muir HM (1962) A modified uronic acid carbazole reaction. Anal Biochem 4:330-334

Blanchard GF, Paterson DM, Stal LJ, Richard P and 8 others (2000) The effect of geomorphological structures on potential biostabilization by microphytobenthos on intertidal mudflats. Cont Shelf Res 20:1243-1256

Borch NH, Kirchmann DL (1997) Concentration and composition of dissolved combined neutral sugars (polysaccharides) in seawater determined by HPLC-PAD. Mar Chem 57:85-95

Chiovitti A, Higgins MJ, Harper RE, Wetherbee R, Bacic A (2003) The complex polysaccharides of the raphid diatom Pinnularia viridis (Bacillariophyceae). J Phycol 39:543-554

Chiovitti A, Molino P, Crawford SA, Teng R, Spurck T, Wetherbee $\mathrm{R}$ (2004) The glucans extracted with warm water from diatoms are mainly derived from intracellular chrysolaminaran and not extracellular polysaccharides. Eur J Phycol 39(2):117-128

de Brouwer JFC, Stal LJ (2001) Short-term dynamics in microphytobenthos distribution and associated extracellular carbohydrates in surface sediments of an intertidal mudflat. Mar Ecol Prog Ser 218:33-44

de Brouwer JFC, Stal LJ (2002) Daily fluctuations of exopolymers in cultures of the benthic diatoms Cylindrotheca closterium and Nitzschia sp. (Bacillariophyceae). J Phycol 38:1-10

de Brouwer JFC, de Deckere EMGT, Stal LJ (2003) Distribution of extracellular carbohydrates in three intertidal mudflats in Western Europe. Estuar Coast Shelf Sci 56:313-324

Decho AW (1990) Microbial exopolymer secretions in ocean environments. Their role(s) in foodwebs and marine processes. Oceanogr Mar Biol Annu Rev 28:73-153

Dong LF, Thornton DCO, Nedwell DB Underwood GJC (2000) Denitrification in sediments of the River Colne estuary, England. Mar Ecol Prog Ser 203:109-122

Dubois M, Gilles KA, Hamiltion JK, Rebers PA, Smith F (1956) Colorimetric method for determination of sugars and related substances. Anal Chem 28:350-356

Eaton JW, Moss B (1966) The estimation of numbers and pigment content in epipelic algal populations. Limnol Oceanogr 11:584-595

Ford CW, Percival E (1965) The carbohydrates of Phaeodactylum tricornutum. Part I. Preliminary examination of the organism, and characterisation of low molecular weight material and of a glucan. J Chem Soc 70:35-41

Giroldo D, Vieira AAH, Paulsen BS (2003) Relative increase of deoxy sugars during microbial degradation of an extracellular polysaccharide released by a tropical freshwater Thalassiosira sp. (Bacillariophyceae). J Phycol 39: 1109-1115

Hoagland KD, Rosowski JR, Gretz MR, Roemer SC (1993) Diatom extracellular polymeric substances: function, fine structure, chemistry, and physiology. J Phycol 29:537-566

Kocum E, Underwood GJC, Nedwell DB (2002) Simultaneous measurement of phytoplankton primary production, nutrient and light availability along a turbid, eutrophic UK east coast estuary (the Colne Estuary). Mar Ecol Prog Ser 231: $1-12$

Lind JL, Heimann K, Miller EA, van Vliet C, Hoogenraad NJ, Wetherbee R (1997) Substratum adhesion and gliding in a diatom are mediated by extracellular proteoglycans. Planta 203:213-221

Oxborough K, Hanlon ARM, Underwood GJC, Baker NR (2000) In vivo estimation of the photosystem II photochemical efficiency of individual microphytobenthic cells using high-resolution imaging of chlorophyll a fluorescence. Limnol Oceanogr 45:1420-1425
Paterson DM (1986) The migratory behavior of diatom assemblages in a laboratory tidal micro-ecosystem examined by low temperature scanning electron microscopy. Diatom Res 1:227-239

Paterson DM (1989) Short-term changes in the erodibility of intertidal cohesive sediments related to the mirgratory behavior of epipelic diatoms. Limnol Oceanogr 34(1): 223-234

Paterson DM, Perkins RG, Consalvey M, Underwood GJC (2003) Ecosystem function, cell micro-cycling and the structure of transient biofilms. In: Krumbein WE, Paterson DM, Zavarzin GA (eds) A natural history of life on earth? Kluwer Academic Publishers, Dordrecht

Perkins RG, Underwood GJC, Brotas V, Snow GC, Jesus B, Ribeiro L (2001) Responses of microphytobenthos to light: primary production and carbohydrate allocation over an emersion period. Mar Ecol Prog Ser 223:101-112

Riethmuller R, Hakvoort JHM, Heineke M, Heymann K, Kuhl H, Witte G (1998) Relating erosion shear stress to tidal flat surface colour. Geol Soc Lond Spec Publ 139:283-293

Riethmuller R, Heineke M, Kuhl H, Keuker-Rudiger R (2000) Chlorophyll a concentration as an index of sediment surface stabilisation by microphytobenthos? Cont Shelf Res 20:1351-1372

Round FE, Crawford RM, Mann DG (1990) The diatoms: biology and morphology of the genera, 1st edn. Cambridge University Press, New York

Smith DJ, Underwood GJC (1998) Exopolymer production by intertidal epipelic diatoms. Limnol Oceanogr 43: 1578-1591

Smith DJ, Underwood GJC (2000) The production of extracellular carbohydrates by estuarine benthic diatoms: the effects of growth phase and light and dark treatment. J Phycol 36:321-333

Staats N, de Winder B, Stal LJ, and Mur LR (1999) Isolation and characterization of extracellular polysaccharides from the epipelic diatoms Cylindrotheca closterium and Navicula salinarum. Eur J Phycol 34:161-169

Staats N, Stal LJ, DeWinder B, Mur LR (2000) Oxygenic photosynthesis as driving process in exopolysaccharide production of benthic diatoms. Mar Ecol Prog Ser 193: 261-269

Stal LJ (2003) Microphytobenthos, their extracellular polymeric substances, and the morphogenesis of intertidal sediments. Geomicrobiol J 20:463-478

Sutherland TF, Grant J, Amos CL (1998) The effect of carbohydrate production by the diatom Nitzschia curvilineata on the erodibility of sediment. Limnol Oceanogr 43:65-72

Taylor IS, Paterson DM, Mehlert A (1999) The quantitative variability and monosaccharide composition of sediment carbohydrates associated with intertidal diatom assemblages. Biogeochemistry 45:303-327

Thornton DCO, Dong LF, Underwood GJC, Nedwell DB (2002) Factors affecting microphytobenthic biomass, species composition and production in the Colne Estuary (UK). Aquat Microb Ecol 27:285-300

Underwood GJC (2002) Adaptations of tropical marine microphytobenthic assemblages along a gradient of light and nutrient availability in Suva Lagoon, Fiji. J Phycol 37: 449-462

Underwood GJC, Kromkamp J (1999) Primary production by phytoplankton and microphytobenthos in estuaries. Adv Ecol Res 29:93-153

Underwood GJC, Paterson DM (1993) Recovery of intertidal benthic diatoms from biocide treatment and associated sediment dynamics. J Mar Biol Assoc UK 73:25-45

Underwood GJC, Paterson DM (2003) The importance of 
extracellular carbohydrate production by marine epipelic diatoms. Adv Bot Res 40:184-240

Underwood GJC, Smith DJ (1998a) In situ measurements of exopolymer production by intertidal epipelic diatomdominated biofilms in the Humber estuary. In: Black KS, Paterson DM, Cramp A (eds) Sedimentary processes in the intertidal zone. Geological Society, London, p 125-134

Underwood GJC, Smith DJ (1998b) Predicting epipelic diatom exopolymer concentrations in intertidal sediments from sediment chlorophyll a. Microb Ecol 35:116-125

Underwood GJC, Paterson DM, Parkes RJ (1995) The measurement of microbial carbohydrate exopolymers from intertidal sediments. Limnol Oceanogr 40:1243-1253

Underwood GJC, Phillips J, Saunders K (1998) Distribution of estuarine benthic diatom species along salinity and nutrient gradients. Eur J Phycol 33:173-183

Underwood GJC, Boulcott M, Raines CA, Waldron K (2004) Environmental effects on exopolymer production by marine benthic diatoms - dynamics, changes in composition and pathways of production. J Phycol 40:293-304

van Duyl FC, de Winder B, Kop AJ, Wollenzien U (1999) Tidal coupling between carbohydrate concentrations and bacterial activities in diatom-inhabited intertidal mudflats. Mar Ecol Prog Ser 191:19-32

Wang Y, Chen Y, Lavin C, Gretz MR (2000) Extracellular matrix assembly in diatoms (Bacillariophyceae). IV. Ultrastructure of Achnanthes longipes and Cymbella cistula as

Editorial responsibility: William Li, Dartmouth, Nova Scotia, Canada revealed by high-pressure freezing/freeze substitution and cryo-field emmission scanning electron microscopy. J Phycol 36:367-378

Widdows J, Brinsley MD, Salkeld PN, Lucas CH (2000a) Influence of biota on spatial and temporal variation in sediment erodability and material flux on a tidal flat (Westerschelde, The Netherlands). Mar Ecol Prog Ser 194:23-37

Widdows J, Brown S, Brinsley MD, Salkeld PN, Elliot M (2000b) Temporal changes in intertidal sediment erodability: influence of biological and climatic factors. Cont Shelf Res 20:1275-1289

Wustman BA, Gretz MR, Hoagland KD (1997) Extracellular matrix assembly in diatoms (Bacillariophyceae). I. A model of adhesives based on chemical characterization and localization of polysaccharides from the marine diatom Achnanthes longpipes and other diatoms. Plant Physiol 113:1059-1069

Yallop ML, Paterson DM, Wellsbury P (2000) Interrelationships between rates of microbial production, exopolymer production, microbial biomass, and sediment stability in biofilms of intertidal sediments. Microb Ecol 39:116-127

Zar JH (1999) Biostatistical analysis, 4th edn. Prentice Hall, Upper Saddle River, NJ

Zhou J, Mopper K, Passow U (1998a) The role of surfaceactive carbohydrates in the formation of transparent exopolymer particles by bubble adsorption of seawater. Limnol Oceanogr 43:1860-1871

Submitted: August 3, 2004; Accepted: December 15, 2004 Proofs received from author(s): February 1, 2005 